\title{
Uluslararası Çalışma Örgütü ve Eğitim
}

\author{
DOI: $10.26466 /$ opus. 906780 \\ * \\ Hüseyin Yolcu* - Engin Alaca** \\ * Prof. Dr., Kastamonu Üniersitesi, Eğitim Fakültesi, Kastamonu/Türkiye \\ E-Posta: $\underline{\text { h.yolcu72@gmail.com }}$ \\ ORCID: $\underline{0000-0001-9974-8446}$ \\ ** Dr. Öğr., Anadolu Üniversitesi, Sosyal Bilimler Enstitüsü, Şehir/Türkiye \\ E-Posta: enginalaca@anadolu.edu.tr \\ ORCID: $\underline{0000-0003-1335-9277}$
}

\section{Öz}

Bu çalışmada, Uluslararası Çalışma Örgütü (ILO) ve bu örgütün eğitim hizmet alanına yönelik yürütmüş olduğ $u$ faaliyetler ele alınmıştır. ILO, gerek örgütsel düzeyde gerekse diğger uluslararası örgütlerle iş birliği halinde eğitim hizmet alanına yönelik birtakım faaliyetler yürütmektedir. Çocuk işçiliğini önlemeye yönelik etkin bir mücadele sergileyen ILO, eğitimde cinsiyet eşitliğine ve erken çocukluk eğitimine ilişkin faaliyetlerde bulunmaktadır. Örgüt, eğitim emekçilerinin toplu pazarlı, istihdam koşulları ve mesleki haklarının iyileştirilmesiyle ilgili birtakım tavsiye niteliğinde kararlar almaktadır. Bu bağlamda, bu tavsiye kararlarının üye ülkeler tarafindan eğitim politikalarına ne düzeyde yansitıldı̆̆ıı izlemekte ve raporlaştırmaktadır. ILO özellikle yoksul ülke ve bölgelerde; çocukların, gençlerin ve mültecilerin eğitime erişim sorunlara yönelik çalışmalara yer vermektedir. Örgütün yaptı̆̆ bu çalışmalar her ne kadar insani bir boyut taşıyor olsa da örgüt ve örgüt yapısını uzun vadede kapitalist liberal ekonominin insana bakış açısıyla yakından ilişkilidir. ILO ve Birleşmiş Milletler Ĕ̆itim, Bilim ve Kültür Örgütü'nün (UNESCO) tavsiye kararlarının kamu kesimini temsil eden hükümetler, özel kesimi temsil eden işverenler ile sendikalarca eğitim ve eğitim emekçileriyle ilgili politikaların belirlenmesinde hangi düzeyde yol gösterici olduğunun ortaya konulmasına yönelik araştırmaların yapılması önerilmektedir.

Anahtar Kelimeler: Eğitim, Uluslararası çalışma örgütü, Eğitim hizmet alanı. 


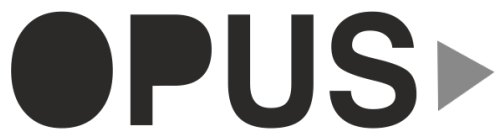

Uluslararası Toplum Araştırmaları Dergisi International Journal of Society Researches
E-ISSN : 2528-9535

Yıl Year:11

Cilt Volume: 18

Sayı Issue :Yönetim ve Organizasyon Özel Sayısı

Temmuz July 2021

Makalenin Gelis Tarihi Received Date: 30/03/2021

Makalenin Kabul Tarihi Accepted Date: 09/05/2021

\title{
International Labor Organization and Education
}

\begin{abstract}
This study focuses on the International Labor Organization (ILO) and its educational activities. The ILO carries out a series of education activities both at the organizational level and in collaboration with other international organizations. The ILO effectively struggles to prevent child labour and also carries out activities for gender equality in education and early childhood education. The organization makes a series of recommendations on collective bargaining, employment terms and conditions and improvement of the professional rights of teachers. It monitors and reports the extent to which these recommendations are incorporated by the Member States in their education policies. Furthermore, ILO works on the problems of children, youth and refugees to access to education especially in impoverished countries and regions. The governments that represent the public sector, the employers that represent the private sector of ILO's recommendations and the trade unions are recommended to conduct researches to put forth the level of guidance in determining the policies related to education and teachers.
\end{abstract}

Keywords: Education, International labor organization, Educational service area 


\section{Giriş}

Eğitim, yaşamın her alanında ve aşamasında ayrı bir önem üzerine konumlandırılmıştır. Eğitim hizmeti alanının başrol oyuncuları olan eğitim emekçilerinin; çalışma koşulları, mesleki eğitim, mesleki özgürlük, çalışma saatleri, maaşlar, bireysel hak ve özgürlükler, istihdam hüküm ve koşulları, iş güvenliği, istihdam şart ve koşullarının müzakeresi (oylaşması), tarafsız akademik değerlendirme gibi yaşamsal olguların tartışılması, iyileştirilmesi ve korunması için politikalar üretilmesinde uluslararası örgütler önemli rol oynamaktadır. Bu ötgütlerden biri de Uluslararası Çalışma Örgütü'dür (ILO).

ILO'nun Anayasası'nda eğitime yapılan atıflar genellikle çocuk işçiliği ve çocuk işçiliğinin önlenmesi başlıkları altında olmakla birlikte eğitime verilen önem geniş ve vurgulu olarak şu biçimde dile getirilmiştir: "Üyeler, ekonomik ve sosyal kalkınmanın, yoksulluğun ortadan kaldırılması programlarının ve evrensel eğitimin desteklenmesini de içerecek biçimde uluslararası işbirliği ve/veya yardımlaşmanın artırılması suretiyle bu Sözleşme hükümlerini yürürlüğe koymak üzere birbirlerine yardımcı olmak için uygun önlemleri alırlar (8. madde)." (ILO, 2014). Diğer yandan ILO'ya (2020a) göre eğitim, toplumlar ve ekonomiler için çok önemlidir. Ekonomik büyümenin, üretkenliğin, işgücü piyasası performansının, beşerî sermaye kazanımlarının ve sosyal hareketliliğin sağlayıcısıdır. Eğitim, kalkınmanın ve özellikle sürdürülebilir kalkınmanın çok önemli bir bileşenidir. Bu nedenle, eğitim, her zaman küresel kalkınma çabalarının ayrılmaz bir parçası olmuştur. Özellikle işgücü piyasası söz konusu olduğunda, eğitim bir ilerleme unsuru olarak görülebilir. Eğitim aynı zamanda işgücü üretkenliğinin bir itici gücü olup iş̧̧ilerin becerilerini ve yetkinliklerini artırmalarına izin verir.

Bu çalışmada, ILO'nun eğitim hizmet alanına yönelik örgütsel düzeyde ve çeşitli uluslararası örgütlerle iş birliği çerçevesinde yürütmüş olduğu faaliyetlerin betimlenmesi amaçlanmıştır. Çalışmada öncelikle ILO'nun kuruluşu, amacı, örgüt yapısı ve finansman kaynakları ele alınmışır. Bunu takiben, ILO'nun gerek örgütsel düzeyde gerekse de diğer uluslararası örgütlerle birlikte eğitimle ilgili yürütmüş olduğu ortak faaliyetler üzerinde durulmuş, çalışmanın sonunda ise konu ile ilgili bir tartışma yürütülmüş, sonuç ve önerilere yer verilmiştir. 


\section{ILO'nun Kuruluşu ve Amacı}

ILO'nun resmi kuruluşu 11 Nisan 1919'da gerçekleşmiştir. Ancak örgütün düşünsel dayanakları ve örgütün kurulmasına yönelik ideolojik zemin Sanayi Devrimi sonrasındaki ortaya çıkan "proleterya (emekçi/işçi sınıfi)" ve işçi sınıfı sorunları olmuştur. Bu sorunlara çözüm arama çabaları ve Sanayi Devrimi'yle birlikte ortaya çıkan kötü çalışma koşullarına karşı beliren Marksist ve Reformist düşünce sistemleri de diğer etkenlerdir (Sevgi, 2014). Sanayi Devrimi öncesinde emek ile sermaye ayrımı belirgin olmadığ gibi loncalardaki ilişkiler de usta-çırak ilişkisi şeklinde gerçekleşmiştir (Koray, 1987). Sanayi Devrimi'yle birlikte buhar gücü keşfedilmiş, önce buharlı makinelerin, akabinde üretim bantlarının sanayiye katılımıla salt insan emeğiyle üretim yapan küçük işletme ve atölyeler yerlerini onlarca, yüzlerce işçinin çalıştığı dev fabrikalara bırakmıştır. Üretimin fabrikalarda gerçekleştirilmeye başlanılmasıyla birlikte loncalar önemini yitirmiştir. Yaşanan bu süreç aynı zamanda lonca sisteminde daha önce var olan ustaçırak ilişkisi, yerini işveren-işçi ilişkisine bırakmıştır. Üretim ilişkilerindeki bu dönüşüm beraberinde işçi sınıfının üretim sürecindeki önemini arttırmış ve bu yeni sınıfı tarih sahnesine taşımıştır.

Makineleşmiş sanayi ve sermaye birikimi sonucu insan emeği sömürülmeye başlanmıştır. Ülkelerin iş ve işçi hakları alanında yasal düzenlemelerinin hiç olmaması ya da yetersiz olması sonucunda ezilen ve köleleştirilen işçi sınıfı daha çok düşünsel bağlamda hak arama mücadelesi vermeye başlamıştır. Sevgi'ye (2014) göre belirli bir aşamadan sonra Marksist ve Reformist düşünce sistemlerinin örgütleri uluslararası alanda rekabet etmeye başlamışlardır. Bu rekabetin somut dayanaklarından biri de Birinci Dünya Savaşı'ndan sonra kurulan ILO olmuştur. ILO, evrensel ve kalıcı barışın ancak sosyal adalet temelinden hareketle kurulup korunabileceği inancından hareketle, Birinci Dünya Savaşı'na son veren Versay Antlaşması kapsamında kurulmuştur. ILO'nun bir anayasası bulunmaktadır. Bu Anayasa, Barış Konferansı tarafından oluşturulmuştur. Söz konusu bu anayasa ilk önce Paris'te, daha sonra Versay'da toplanan Çalışma Komisyonu tarafından 1919 yılının Ocak ve Nisan ayları arasında hazırlanmıştır (Hasgüler ve Uludağ, 2014; ILO, 2020a). Örgüt, Aralık 1946'da Birleşmiş Milletler (BM) ile bağlantılı ilk uzman kuruluş olmuş ve bu nedenle aynı yıl örgütün anayasasında bazı düzenlemeler yapılmıştır (Schiavone, 2008). 
Ateş (2014), 1919 yllında toplanan Paris Barış Konferansı'nda komisyonlarda ortaya çıkan sözleşmelerin doğrudan Versay Barış Anlaşması'na dahil edilerek galip devletlerce (İngiltere, Fransa, İtalya ve Amerika Birleşik Devletleri [ABD]) imzalandığını, mağlup devletlere ise (Osmanlı İmparatorluğu, Almanya, Bulgaristan ve Avusturya-Macaristan İmparatorluğu) zorla imzalattırıldığını belirtmektedir. Bununla birlikte baştaki amaç ne olursa olsun ILO'nun yapmış olduğu faaliyetlerin sonucunda sanayileşmiş ülkelerdeki işçilerin çalışma koşulları iyileşmeye başlamıştır. Gürsel (2016), ILO'nun BM bünyesinde oluşturulmuş ve alanında uzman bir örgüt olmasının yanı sıra, temel insan hakları, sosyal adalet ve çalışma haklarının iyileştirilmesine yönelik çalışmalar yürüttüğünü belirtmektedir. Hasgüler ve Uludağ'ın (2014) belirttiği gibi örgüt, 50. kuruluş yıldönümü olan 1969 yılında, yaptığı çalışmalardan ötürü Nobel Barış Ödülü'ne layık görülmüştür.

ILO'nun amacl; sosyal adaletin sağlanması yolunda çaba göstererek sürekli bir barışın kurulmasına destek olmak, uluslararası faaliyetlerle çalışma şartlarını ve yaşam niteliğini yenilikçi biçimde tekrar düzenleyerek ekonomik ve sosyal istikrara katkıda bulunmaktır (Hasgüler ve Uludağ, 2014). Bu amaç doğrultusunda ILO'nun üzerinde durduğu dört stratejik hedefi bulunmaktadır. Bunlar; (1) Çalışma yaşamına ilişkin standartlar, temel ilke ve haklar geliştirmenin yanı sıra bunların uygulamaya geçirilmesini gerçekleştirmek, (2) Kadın ve erkeklerin insana yakışır işlerde çalışabilmesi için daha fazla fırsat yaratmak, (3) Sosyal koruma programlarının kapsamını ve etkinliğini artırmak ve (4) Üçlü yapıyı (işveren, işçi ve hükümet) ve sosyal diyalogu güçlendirmektir (Özgöker, 2014).

\section{Örgüt Yapısı ve Finansmanı}

Örgütün en yüksek organı Genel Konferans'tır. Bu organın temel görevi, uluslararası sosyal standartları düzenleyen ve biçimlendiren sözleşmeler hazırlamaktır. Aynı zamanda bu organ örgüt yönetim kurulunu seçmektedir (Hasgüler ve Uludağ, 2014). Sengenberger'e (2014) göre, ILO iki temel karar organına sahip olup bu organlardan biri "Dünya Çalışma Parlamentosu" olarak da bilinen Uluslararası Çalışma Konferansı, diğeri de ILO Yönetim Kurulu'dur ve her iki yapıda da ulusal hükümetler koltukların yarısına sahiptirler; işçi ve işveren taraflarının her biri ise örgütün oy hakkının çeyrek 
kısmını ellerinde bulundurmaktadırlar. ILO'nun faaliyetlerini hükümet, işveren ve işçi kesimi temsilcilerinin de yer aldığı; Uluslararası Çalışma Konferans1, ILO Yönetim Kurulu ve ILO Ofis'den oluşan üçlü ana yapı gerçekleştirmektedir (ILO, 2020d). Sıkça "emeğin uluslararası parlamentosu" olarak atıfta bulunulan Konferans, belli başlı toplumsal ve çalışma yaşamına ilişkin konuların tartışıldığı bir forum durumundadır. Yönetim kurulu ILO'nun icra organı olup yılda üç kez Cenevre'de toplanmaktadır. Kurul, ILO politikalarına ilişkin kararları almanın yanı sıra, onaylanmak üzere Konferansa sunulacak programı ve bütçeyi de hazırlamaktadır. Uluslararası Çalışma Ofisi, ILO'nun daimî sekretaryası ve operasyonel merkezidir. İdare ve yönetim ise Genel Direktör önderliğinde bölgesel, yerel ve $40^{\prime} 1$ aşkın ülkede bulunan temsilcilikler aracilığıyla merkezi bir yapıda uygulanır. ILO sekretaryası, operasyonel merkezi, araştırma merkezi ve yayınevi Cenevre'de bulunan Uluslararası Çalışma Ofisi'ndedir.

Örgütün en yetkili organı olan Genel Konferans toplantılarına katılan üye ülke heyetlerinde; ikisi hükümet, biri işveren ve biri de iş̧̧i temsilcisi olmak üzere dört üye bulunur. Bu üç taraflı temsile komünist ideoloji penceresinden bakıldığında; devletler, işverenler ve işçiler arasındaki çıar ilişkilerinin bu temsil sistemini etkisizleştirmekte olduğu ve bunun sonucu olarak da komünist delegeler arasında farklı çıkarların ve görüşlerin olmadığı eleştirileriyle karşılaşılmaktadır. Ancak genel olarak bu üç parçalı temsil formülü ILO'da takdir görmekte ve desteklenmektedir. Genel Konferans ayrıca 112 üyeden oluşmakta olan Yönetim Kurulu'nu seçmekle görevlidir. Kurulun 56 üyesini hükümet temsilcileri, 28 üyesini işveren ve 28 üyesini de işçi temsilcileri oluşturur. Örgütün karar alma mekanizmasında oybirliği esastır. Böylece hiçbir üyenin karşı çıkmadığı tasarılar karara dönüşmekte ve bu kararlar bütün üye ülkeler için bağlayıcı olmaktadır (Bennett ve Oliver, 2015; Hartlapp, 2008; akt. Ateş, 2014).

ILO yapısında bulunan bölgesel konferanslar, belli bir bölgeyi ilgilendiren sorunların tartışılıp çözüm mekanizmalarının devreye sokulduğu oluşumlardır. Bu konferanslar çalışma toplantılarını ilgili bölgelerde üç ya da dört yılda bir yapmaktadırlar. ILO bünyesinde bölgesel konferansların yanı sıra sürekli ve geçici özelliklere sahip komiteler de bulunmaktadır (Hasgüler ve Uludağ, 2014). ILO'nun yaklaşık 40 ülkede şubesi ve çeşitli ülkelerin şehirlerinde de bölge ofisleri bulunmaktadır. Örgütün bölge ofisleri Abidjan (Afrika kıtası için), Lima (Amerika kıtası için), Beyrut (Arap 
ülkeleri için), Bangkok (Asya ve Pasifik için) ve Cenevre'de (Avrupa ve Orta Asya için) konuşlanmıştır (Schiavone, 2008).

Milletler Cemiyeti'nin (MC $)^{1}$ tüm üyelerine yönelik başlangıçta sağlanmış olan ILO doğal üyeliği artık tamamen isteğe bağlı durumdadır. BM üyeleri, mevcut hükümlere uygun olarak ILO'ya katılabilmektedirler. BM üyesi olmayan herhangi bir egemen ülke, hazır bulunan ve oy veren hükümet delegelerinin üçte ikisi de dahil olmak üzere, Uluslararası Çalışma Konferansı oturumuna katılan delegelerin üçte ikisinin onayladığı bir oylamayla ILO'ya kabul edilebilmektedir. Herhangi bir üye ülkenin tek taraflı geri çekilmek istemesi durumunda ise bu konudaki isteğini Genel Direktöre yazılı olarak bildirmek durumundadır. Söz konusu çekilme isteği, onaylanma tarihinden iki yıl sonra yürürlüğe girmektedir. ABD, 1977'de birtakım siyasî gerekçeler sunarak örgütten çekilmiş ancak Şubat 1980'de tekrar geri dönmüştür (Schiavone, 2008). ILO'ya (20201) göre, BM'nin her asıl üyesi ILO Anayasası'ndan doğan yükümlülükleri resmen kabul ettiğini Uluslararası Çalışma Bürosu Genel Müdürü'ne bildirmek suretiyle örgüte üye olabilmektedir. BM'ye üye olmayan bir ülke ise ILO Genel konferansı, hükümet temsilcilerinin üçte ikisinin toplantıda hazır bulunduğu ve oylamaya katıldığı oturumda temsilcilerin üçte ikisinin kabul oyuyla örgüte üye kabul edilebilmektedir. Bu kabul, yeni üye ülke hükümetinin ILO Anayasası'nın getirdiği yükümlülükleri resmen kabul ettiğini Uluslararası Çalışma Bürosu Genel Müdürü'ne bildirmesi durumunda yürürlük kazanmaktadır. Örgütün 2020 yılı itibariyle 185 üyesi bulunmaktadır. Üye olmayan devletler çoğunlukla Avrupa ve Asya-Pasifik'teki Mikronezya, Nauru, Butan Krallığı, Niue gibi küçük ülkelerdir.

Uluslararası örgütlerin kendi bütçelerinin olması bu örgütlerin kendi kararlarını herhangi bir baskıyla karşı karşıya kalmadan alabilmeleri bakımından son derece önemlidir. Buna göre, ILO iki yılda bir gerçekleştireceği faaliyetlerini, hedeflerini ve beklenen olası sonuçlarını belirleyen ILO Programı ve Bütçesi, Uluslararası Çalışma Konferansı tarafından her iki yılda bir onaylanmaktadır. ILO bütçesinin üç ana finansman kaynağ bulunmaktadır (ILO, 2020b; Sevgi, 2014). Bunlardan ilki, üye devletler

\footnotetext{
${ }^{1}$ Milletler Cemiyeti (Cemiyet-i Akvam da denir), günümüzdeki Birleşmiş Milletler'in temeli sayılabilecek bir örgüttür. I. Dünya Savaşı'nın ardından isviçre'de, 10 Ocak 1920'de kurulmuştur. Örgütün amacı, ülkeler arasında yaşanabilecek sorunları barışçı yollarla çözmek idi. Ancak fazla bir varlık gösteremeyen örgüt II. Dünya Savaşı'nın ardından 1946 yılında dağılmuştır (Vikipedi, 2021).
} 
tarafından ödenen aidatların oluşturduğu "düzenli bütçe"; ikincisi, gönüllü bağışları ve proje ortakları tarafından finanse edilen "düzenli bütçe ek hesabı"; üçüncüsü ise belirli projeleri desteklemek için kamu ve özel kuruluşlar, uluslararası finans kuruluşları ve BM kuruluşları dahil olmak üzere 100'den fazla farklı kaynak tarafından finanse edilen "ekstra bütçe"dir. ILO'nun (2020b), 31 Aralık 2021'de sona eren 77. malî dönem için 790.640.000 ABD Doları (\$) tutarında harcama bütçesi finans komitesi tarafından kabul edilmiş ve üye ülkelere paylaştırılmıştır.

\section{ILO'nun Eğitim Hizmet Alanına Yönelik Faaliyetleri}

Bu başlık altında ILO'nun eğitim hizmet alanına yönelik örgütsel düzeyde yaptığı faaliyetler ile diğer uluslararası örgütlerle işbirliği halinde ele aldığ faaliyetlere sırasıyla aşağıda yer verilmiştir.

\section{ILO'nun Örgütsel Düzeyde Eğitim Hizmet Alanına Yönelik Faaliyetleri}

ILO'nun örgütsel düzeyde eğitim hizmet alanına yönelik faaliyetleri; kurumsal yapılanmalar, çocuk işçiliği, çalıştaylar ve raporlar alt başlıkları altında aşağıda sırasıyla ele alınmıştır.

Kurumsal yapılanmalar altında yürütülen faaliyetler: Bennett ve Oliver (2015), ILO'nun eğitim ve öğretim alanında iki önemli kuruma sahip olduğunu belirtmektedir. Bunlardan biri 1961'de Cenevre'de kurulmuş olan Uluslararası İş Çalışmaları Enstitüsü'dür (International Institute for Labor Studies, IILS). IILS; devletler, sanayi liderleri ve araştırmacılar için sosyal politika ve çalışma politikası kursları düzenlemektedir. Bunun yanı sıra IILS, aynı zamanda gelişmekte olan ülkelerin ulusal eğitim kurumlarında kendi kurslarına benzer liderlik eğitim programları oluşturulması için rehberlik etmektedir. ILO'ya (2020n) göre IILS programlarının temel düzenlenme amac1, insana yakışır iş" temasıdır. Bu doğrultuda IILS'nin programları, "insana yakışır iş" temasının uygulamada gereksinm duyulan politika araçlarının daha geniş bir çerçevede geliştirilmesine katkıda bulunmayı amaçlamaktadır. Diğer yandan IILS'nin verdiği üç temel hizmet; sosyal politikalarda, hükümet, iş dünyası ve çalışanın, akademik çevreler ve diğer fikir üreticileriyle buluşup etkileşime girebilecekleri bir forum olanağı sunulması; 
ILO politikalarının oluşturulması ve araştıılması amacına dayalı olarak uluslararası araştırma programları ve iş dünyası, çalışan ve hükümet yetkilileri ile akademi arasında bağlantı sağlanması; işçi ve işveren örgütleri ve çalışma yönetimlerinin, ekonomik ve sosyal alanlarda araştırma, analiz ve politika oluşturma kapasitelerinin geliştirilmesine yönelik eğitim programları sunulmasıdır. IILS'nin diğer faaliyetleri ise; araştırma, sosyal politika forumları, halka açık dersler, kurslar ve seminerler, staj programları, misafir öğrenci programları, Phelan burs programı ve çeşitli yayınlardır. Bunların yanı sıra IILS, ILO'ya verilen Nobel Barış Ödülü kapsamında, dünyanın önemli üniversitelerinde Sosyal Politika Seminerleri düzenlemektedir.

Bennett ve Oliver'a (2015) göre bu kurumların ikincisi 1965'te İtalya Torino'da kurulmuş olan Uluslararası İleri Teknik ve Mesleki Eğitim Merkezi'dir (International Training Centre, ITC). ITC'nin görevi başlangıçta gelişmekte olan ülkelerden kabul ettiği kişilere, kendi ülkelerinde alabileceklerinden daha ileri düzeyde teknik ve mesleki eğitim vermek ve aynı zamanda eğitmenlere de eğitim vermektir. Ancak ITC'nin görevleri daha sonra bu eğitimlerin yanı sıra sanayileşmiş ve gelişmekte olan ülkelerden gelen yöneticilere yönetim/yöneticilik eğitimi verilmesini de kapsayacak biçimde genişletilmiştir. ILO'ya (2020o) göre üye ülkeler ve sosyal tarafların ekonomik ve sosyal gelişmelerini desteklemek üzere kurulan ve tasarlanan ITC, kadın ve erkekler için iş ve gelir elde etme olanağı, herkes için sosyal koruma, kalkınma süreci yönetimi, üçlü yapı ve sosyal diyalog ile ilgili pratik ve deneyimi birlikte sunmayı amaçlamaktadır. Kuruluşundan (1965) günümüze kadar 170 ülkeden 90.000'in üzerinde kadın ve erkek ITC aracılığıyla verilen eğitim hizmetlerinden yararlanmıştır. Etkinliklerin yarıya yakını ITC'nin bulunduğu yerleşkede, geri kalan kısmı ise alanda/sahada gerçekleştirilmektedir. Bunun yanı sıra ITC, talep edildiği takdirde kamu ve özel kuruluşlarda çalışan kişiler için de eğitim programları düzenlemektedir. Daha uzak ve merkeze erişimin zor olduğu bölgelere yönelik eğitim ve öğretim hizmetlerinin yerine getirilmesinde internet de (uzaktan öğretim) dahil olmak üzere çeşitli bilgi teknolojileri ile hizmet verilmektedir

Çocuk işçiliğine yönelik çalışmalar: ILO'nun az gelişmiş ve temel insani gereksinimlere erişimin çok kısıtlı olduğu coğrafyalarda da eğitim konusunda araştırmalar yaptığı görülmektedir. ILO'nun (2016) “'Afrika'daki kırsal öğretmenler: Bir ILO Raporu (Rural teachers in Africa: A report for 
ILO)" adlı çalışmada kırsal alanlarda eğitime erişimin olmamasının eğitimdeki temel kalkınma zorluklarından biri olduğuna dikkat çekilmektedir. Rapora göre, kırsal alanlarda ilkokula kaydolma oranlarının çoğu gelişmekte olan ülkelerdeki kentsel oranların çok gerisindedir. Üstelik, kırsal alanlarda öğrenme sonuçları daha düşük olup kızların eğitimlerini tamamlama oranlarını kentsel alanlardakilerle karşılaştırıldığında oldukça düşüktür. Bunun yanı sıra, kırsal alanlarda görev yapan öğretmenlerin niteliklerinin düşük olduğu belirtilmektedir. Çalışmada kırsal öğretmen sorununa Afrika'nın tepkileri incelenmekte ve kırsal alanlar için nitelikli öğretmenleri teşvik etmeyi amaçlayan uygulamalar ve yaklaşımlar sunulmaktadır.

18-20 Eylül 2018 tarihinde ILO ve üye ülkeler tarafından İsviçre'nin Cenevre şehrinde "Yükseköğretimde İstihdam Hüküm ve Koşulları Üzerine Küresel Diyalog Forumu" toplantısı düzenlenmiştir. Bu toplantıda, ILO ve üyelerinin gelecekteki eylemleri için tavsiyeler de dahil olmak üzere, düşünce birliği noktalarının benimsenmesi amaçlanmıştır. Söz konusu toplantıda pazarlık ve yükseköğretimde meslek yönetimi de dahil olmak üzere istihdam şart ve koşulları, mesleki haklar ve sosyal diyalog mekanizmaları ele alınmıştır. Toplantının mutabakat başlıkları arasında; yükseköğretimde istihdam koşullarına ilişkin zorluklar ve fırsatlar, hükümetlerin ve sosyal ortakların problemleri daha iyi ele alması, yükseköğretimdeki firsatlardan yararlanılması için atabilecekleri adımlar ile ILO ve üyelerinin gelecekteki eylemleri için öneriler yer almaktadır (ILO, 2020h). Forumun final raporunda belirtildiğine göre forumda 26 üye devletten 42 hükümet delegesi ve danışmanlarının yanı sıra sekiz işveren ve sekiz işçi delegesi, işçi grubundan bir danışman, hükümetler arası kuruluşlardan ve uluslararası sivil toplum kuruluşlarından beş gözlemci de dahil olmak üzere 63 katılımcı yer almıştır (ILO, 2019).

ILO'nun (2020ö) COVID-19 ve Eğitim Sektörü (COVID-19 and The Education Sector) adlı çalışmasında; ILO'nun çocuk işçiliğini ortadan kaldırmaya yönelik projelerinden elde edilen bilgiler, çocuk işçiliği içinde bulunan veya bu risk altında bulunan okul çocuklarının uzaktan eğitime erişim olasılıklarının daha da düşük olduğunu gösterdiği belirtilmektedir. Bu tür dezavantajlı topluluklarda, genellikle düşük teknolojili veya teknolojisiz olan uzaktan eğitimin niteliği zayıf olabilmektedir. Pandemi sırasında ve sonrasında eğitim sistemlerinde yüksek oranda okulu bırakma riski ve çocuk işçiliğinin artması riski de yüksektir. ILO'nun da üyesi olduğu Uluslararası 
Eğitim İçin Öğretmenler Görev Gücü 2030 (International Task Force on Teachers for Educations 2030-Teacher Task Force), COVID-19 nedeniyle; maaşların aksatılmaması, öğretmenlerin ve öğrencilerin sağlık, güvenlik ve refahına öncelik verilmesi; öğretmenlerin istihdamlarının korunması için hükümetleri, eğitim sağlayıcıları ve fon sağlayıcılarını ve tüm ilgili ortakları kapsayan Öğretmenler için Eylem Çağrısı yayınlamıştır (ILO, 2020c).

\section{ILO'nun Diğer Uluslararası Örgütlerle Birlikte Eğitim Hizmet Alanına Yönelik Yürütmüş Olduğu Ortak Faaliyetleri}

ILO diğer uluslararası örgütlerle birlikte eğitim hizmet alanına yönelik ortak faaliyetlerde bulunmaktadır. ILO'nun bu örgütlerden BM Eğitim, Bilim ve Kültür Örgütü'ne (United Nations Educational, Scientific and Cultural Organization, UNESCO) ve Birleşmiş Milletler Çocuklara Yardım Fonu (United Nations International Children's, UNICEF) ile birlikte yürütmüş olduğu faaliyetler aşağıda verilmiştir.

UNESCO ile birlikte yürütülen ortak faaliyetler: ILO'nun UNESCO ile birlikte eğitim hizmet alanına yönelik gerçekleştirmiş olduğu faaliyetler arasında; tavsiye kararları, cinsiyet eşitliğini sağlama ve erken çocukluk dönemine ilişkin faaliyetler yer almaktadır. Söz konusu bu faaliyetler aşağıda sırasıyla ele alınmıştır.

Tavsiye kararları: ILO ve UNESCO'nun “Öğretmenlerin Statüsüne İlişkin Tavsiyesi (1966)" ve "Yüksek Öğretim Personelinin Statüsüne İlişkin Tavsiye Kararı (1997)" okul öncesinden üniversiteye kadar tüm öğretim düzeylerinde çalışan eğitim emekçilerinin hakları ve sorumluluklarını belirleyen iki uluslararası belgedir. Her iki tavsiye belgesi; hükümetler, işverenler, öğretmenler, sendikalar ve üye ülkelerin üretecekleri eğitim ve eğitim emekçileriyle ilgili politikalar için rehberlik sağlamaktadır (ILO ve UNESCO, 2019a). $\mathrm{Bu}$ tavsiyeler, eğitim emekçilerinin kişisel gelişimi ve eğitimini ve toplumun çıkarları için onların sosyal ve kamusal yaşama katılımını teşvik etmektedir. Ayrıca eğitim emekçilerinin genel olarak yararlandıkları tüm yurttaşlık haklarını kullanmakta özgür olmaları çağrısında bulunmaktadır (ILO, 2012). Söz konusu tavsiye belgelerinin birkaç açıdan önemli olduğu söylenebilir. Bunlardan ilki, bu tavsiye belgelerinin doğrudan eğitim emekçilerini konu 
edinmiş olmalarıdır. İkincisi, her iki örgütün uzmanlarınca hazırlanan bu belgelerin üye ülkelerin eğitim politikalarına rehberlik ediyor olmasıdır. Üçüncüsü ise ILO ve UNESCO ortak kurulu tarafından yine bu tavsiye belgelerinin üye ülkeler tarafından eğitim politikaları belirlenirken dikkate alınıp alınmadığının değerlendirilip raporlaştırılıyor olmasıdır.

Öğretmenlerin Statüsüne İlişkin Tavsiye (1966), eğitim emekçilerinin çalışma saatlerinin belirlenmesinde; derslerin ve öğrencilerin sayısı, öğrenci toplantıları/danışmanlığı süreleri, denetim görevleri, müfredat dışı etkinliklerin yoğunluğu, veli toplantıları, idari sorumluluklar gibi değişkenlerin göz önünde bulundurulmasını tavsiye etmektedir. Tavsiye Kararında, bu süreçte öğretmen kuruluşlarına danışılması gerektiğini ve çalışma koşullarının müzakerelerin temel konusu olması gerektiğini açıkça belirtilmektedir. Yine 1966 Tavsiyesi, tıbbî bakım ve rehabilitasyon hizmetlerinin engelli öğretmenlere sunulması çağrısında bulunmaktadır. Tavsiye; genel olarak engellilerin ve özel olarak öğretmenlerin haklarını koruyan yasaların çıkarılması, okul altyapısının engelli öğretmenler ve öğrenciler için yeterli olmasının sağlanması; uyarlanmış öğretim materyalleri ve öğretim programları ve yardımc cihazlar da dahil olmak üzere gerektiği biçimde engelli öğretmenlere makul düzenlemeler sağlanması, engelli öğretmenler için özel giriş, istihdam, terfi ve izin sürelerinin geliştirilmesi dahil olmak üzere olumlu eylem önlemlerinin alınması için çağrıda bulunmaktadır (ILO, 2012).

1966 Tavsiyesi, okul öncesi dönemden başlayarak ortaöğretime kadar olan özel ya da kamu tüm eğitim kurumlarındaki öğretmenleri kapsamaktadır. 1997 Tavsiye Kararı ise 1966 Tavsiye Kararı'nı tamamlamakta olup tüm yükseköğretim ve araştırma personelini kapsar (ILO ve UNESCO, 2019a). ILO ve UNESCO iş birliğiyle başlatılan Nitelikli Öğretim İlkelerinin Teşviki Çalışması, 1966 Tavsiyesi ile okul öncesi eğitiminden ortaöğretim düzeyine kadar olan eğitim emekçilerini kapsamaktayken 1997 Tavsiye Kararıyla üniversite (yükseköğretim) de dahil olmak üzere bütün eğitim-öğretim personelini de içererek biçimde bir bütün oluşturmuştur. Dolayısıyla her iki uluslararası örgüt sadece ortaöğretime kadar olan eğitim emekçilerini değil, aynı zamanda yüksek öğretim düzeyindeki öğretim kurumlarında görev yapan eğitim emekçilerini de bu gruba dahil ederek onları ve onların kurumların da nitelikli öğretim ilkelerinin teşvikiyle ilişkilendirmiştir.

1966 Tavsiyesi; profesyonellik, politikalarda iş birliği, öğretmen eğitimi, mesleki özerklik, sorumluluklar, haklar, çalışma saatleri, maaşlar, öğretmen 
açığı alanlarını kapsamaktadır. 1997 Tavsiye Kararı'nın kapsadığı alanlar ise; profesyonellik, kurumsal özerklik ve hesap verebilirlik, bireysel hak ve özgürlükler, istihdam hüküm ve koşullarl, iş güvenliği, istihdam şart ve koşullarının müzakeresi, tarafsız akademik değerlendirme, kadınların, engellilerin ve yarı zamanlı yükseköğretim personelinin istihdamına ilişkin hüküm ve koşulları içermektedir (ILO ve UNESCO, 2019a). 1966 Tavsiye Kararı'nın kapsadığı alanlar daha çok öğretmenlik mesleğiyle ilgiliyken, 1997 Tavsiye Kararı'nın kapsadığı alan politikaları daha çok yükseköğretim kurumları ve yüksek öğretim personeline yöneliktir.

Yukarıda bahsedilen tavsiye kararları yasal olarak bağlayıcı değildirler. Bir sözleşmeden farklı olarak ulusal onaylamaya tabii olmayan birer tavsiyedirler. Ortak Komite'nin tavsiyeleri; ulusal makamların, işveren ve işçi örgütlerinin ve diğer eğitim kurum ve kuruluşlarının eylemlerine rehberlik etmeyi amaçlamaktadır. Ancak ILO ve UNESCO'ya üye devletler bu tavsiyelerin hükümlerini bilmekle yükümlüdürler. Bu nedenle bu tavsiyeler güçlü bir ikna edici etkiye sahiptir (ILO ve UNESCO, 2019a). Bununla birlikte her ne kadar ILO ve UNESCO'ya üye devletler bu tavsiyelerin hükümlerini bilmekle yükümlü olsalar da bu tavsiyelerin yasal bağlayıcllı̆̆ının olmaması büyük bir handikap olarak düşünülmektedir.

Öğretim personeliyle ilgili tavsiyelerin uygulanmasına ilişkin ortak uzmanlar komitesi, ILO ve UNESCO, Öğretim Personeliyle İlgili Tavsiyelerin Uygulanmasına İlişkin Ortak Uzmanlar Komitesi (Committee of Experts on the Application of the Recommendations Concerning Teaching Personnel, [CEART]) aracılığıyla nitelikli öğretim ilkelerini teşvik etmektedir. CEART, öğretim personeline ilişkin iki uluslararası tavsiyenin ${ }^{2}$ uygulanmasını teşvik etmek ve izlemek için ILO ve UNESCO tarafından ortaklaşa kurulmuştur. CEART, dünyanın dört bir yanından eğitim, öğretim ve iş gücü uzmanlarından oluşmakta, eğitim ve öğretimdeki eğilimleri ve ülkelerin tavsiyeleri nasıl uyguladığını incelemektedir. CEART ayrıca, üye devletlerde tavsiyelerin ilkelerine uyulmaması ile ilgili öğretmen örgütleri tarafından yapılan iddiaları incelemekte ve bu tür vakaların çözümü için bulgular yayımlanmakta ve tavsiyelerde bulunmaktadır (ILO, 2020e).

2 Öğretmenlerin Statüsüne Ilişkin ILO / UNESCO Tavsiyesi (1966) ve UNESCO Yüksek Öğretim Personelinin Statüsüne Ilişkin Tavsiye Kararı (1997). 
CEART, altısı ILO tarafindan altısı da UNESCO tarafindan atanan 12 bağımsız uzmandan oluşmaktadır. CEART, iki tavsiyenin uygulanmasına ilişkin bilgileri ve raporları incelemek için her üç yılda bir toplanmaktadır. $\mathrm{Bu}$ incelemeler sonucunda CEART, dünya çapında ve hükümetlere özel somut eylemler öneren öğretmenlerin durumunu özetleyen kendi raporunu yayınlamaktadır. CEART raporu, ILO Yönetim Kurulu, Uluslararası Çalışma Konferansı, UNESCO Yürütme Kurulu ve tüm üye devletlere gönderilir (ILO ve UNESCO, 2019b). CEART, 13. Oturumunu 1-5 Ekim 2018 tarihleri arasında Cenevre'de ILO merkezinde gerçekleştirmiştir. 13. Oturumda, hem 1966 Öğretmenlerin Statüsüne İlişkin Tavsiye Kararı'nın hem de 1997 Yükseköğretim Personelinin Statüsüne İlişkin Tavsiye Kararı'nın Ortak Komite tarafından izlenmesine ve desteklenmesine odaklanılmıştır (ILO, 2020g). Dünyanın dört bir yanından bağımsız eğitim uzmanlarından oluşan 13. Ortak Komite Oturumu, eğitimin özelleştirilmesi, ortaöğretim sonrası Teknik ve Mesleki Eğitim ve Öğretim (Technical and Vocational Education and Training, TVET) kurumlarında öğretmenler de dahil olmak üzere öğretim personelini etkileyen bir dizi acil konuyu ve eğitim finansmanı konuların incelemiştir. Ortak Komite ayrıca, tavsiyelerin uygulanmasına ilişkin öğretmen sendikalarından gelen bazı iddiaları da ele almıştır (ILO, 2020f).

2018 tarihinde yapılan 13. Oturum sonucunda, ILO Yönetim Kuruluna ve UNESCO Yürütme Kurulu'na ve bunlar aracllığıyla üye devletlerin hükümetlerine, işveren ve işçi örgütlerine, öğretmenlik mesleğinin durumunun nasıl iyileştirilebileceğine dair tavsiyeler içeren bir rapor sunulmuştur. Raporun ana başlıkları; ILO ve UNESCO'nun iki tavsiyeyi teşvik etmek için ortak veya ayrı faaliyetlerin gözden geçirilmesi ve başlıca eğilimlerdir. Söz konusu raporun "Başlıca Eğilimler" alt başlı̆̆ı altında (23. madde) ek bilgi ve görüş sağlamak için ilgili kuruluşlardan davet edilen bir konuşmacı "Lezbiyen, Gey, Biseksüel, Transseksüel ve Travesti (Lesbian, Gay, Bisexual, and Transgender, LGBT) öğretmenlerinin ve yerli ve kabile topluluklarından olanlar gibi belirli öğretmen gruplarının ayrımcılığa maruz kalması" sorununu dile getirmiştir (ILO ve UNESCO, 2018). Görüldügü üzere güncel ve son oturum olan 13. Oturumda öğretmenlere yönelik cinsel yönelim ve etnik temelli ayrımcilık sorunlarının dile getirilmiş olması üye ülkelerde eğitim emekçilerine karşı bu tür grupsal ayrımcılıkların da göz ardı edilmediğini göstermektedir. 13. Oturum 
raporunda aynı başlık altında (25. madde) ise Uluslararası Sendikalar Konfederasyonu'ndan (ITUC) bir temsilci; eğitim hakları ile işçi hakları arasındaki ilginç kesişme noktasına dikkat çekmiştir. Söz konusu temilci, hak temelli bir yaklaşıma gereksinim olduğunu belirtilmiştir. Bununla birlikte, eğitimin metalaştırılması, çeşitli çalışma güvencesizliklerine yol açarak işçi haklarını, özellikle de örgütlenme özgürlügünü tehlikeye attığ 1 ifade edilmiştir. Bir başka endişe konusu da bir sendikaya üye olmanın genellikle siyasallaşmanın bir işareti olarak görülmesi olduğudur. Bu bağlamda, sosyal diyaloğu ve toplu pazarlık hakkını desteklemenin çok önemli olduğu, çoğunlukla piyasa güçleri ve istihdam edilebilirlik eğitimin merkezinde yer alırken, bunların söz konusu olan tek sorun olarak görülmemesi ve eğitimin sosyal değerinin üstün gelmesi gerektiğine değinilmiştir (ILO ve UNESCO, 2018).

ITUC temsilcisinin eğitim hakları ve işçi hakları arasındaki kesişme noktasından hareketle yaptı̆̆ çıkarımlar eğitim emekçileri için hak temelli bir uyanışın önünü açmış olduğu söylenebilir. Eğitimin metalaştırılmasının yol açtı ̆̆ çeşitli hak güvencesizlikleri ve özgürlük kısıtlamalarının özellikle siyasî yozlaşmayla olan ilgisine dikkat çekilmiş ve eğitim emekçilerinin sendikalaşmasının önündeki engeller ve bu engellerin yol açtı̆̆1 olumsuzluklar dile getirilmiştir. Dünya ülkelerinin çoğunda gözlenen taraflı siyasal sendikalar hem sendikalaşma özgürlüğüne aykırıdır hem de eğitim emekçilerinin özgürce örgütlenmesinin önünde bir engel olup eğitimi metalaştırmaktan öteye gitmemektedirler.

Yine 13. Oturum raporu 30. Maddede, göçmen çocukların eğitimleriyle ilgili söz alan BM Mülteciler Yüksek Komiserliği'nin (BMMYK) bir temsilcisinin mültecilerin eğitime erişimde yaşadığı bazı engellere dikkat çekmiştir. Söz konusu bu engeller arasında; mültecilerin yurttaşı oldukları ülkelerden aldıkları eğitim sertifikaları ve diplomaların göç/iltica ettikleri ülkelerde tanınmaması, dil engelleri, malî kısıtlamalar, yüksek öğretime nasıl erişileceğine dair bilgi eksikliği ve sosyo-kültürel normlara ilişkin farklılıklar yer almaktadır (ILO ve UNESCO, 2018). BMMYK temsilcisinin sözlerinden hareketle göçmen çocukların eğitime erişimleriyle ilgili sorunlara ve göçmenlerin yaşadıkları diğer eğitimle ilgili engellere de 13. Oturumda değinilmiştir.

Raporun bildiri kısmında emeğin bir meta olmadığı olgusuna dikkat çekilerek ticarileştirme ve özelleştirmenin bir kamu malı olarak eğitim ve eğitim hakkı için potansiyel olarak olumsuz sonuçları olabileceğinden endişe 
duyulduğu belirtilmiştir. Bildiri kısmında kabul edilen beyanlardan dikkat çekilen noktalar arasında; (1) Eğitimin ekonomik mantığının onun bütüncül işlevini zayıflatmaması, (2) Teknoloji ve teknolojik araç-gereçlerle öğretmenlerin desteklenebileceği ancak teknolojinin onların yerini almaması (3) TVET öğretmenlerinin geleneksel olarak eğitim sistemlerinde yeterince destek görmedikleri ve bu öğretmelerin profesyonel hazırlık firsatlarından yararlandırılmaları, (5) Yükseköğretimde öğretim ve araştırmaya eşit derecede değer verilmesi ve ticari olarak kârlı olan alanlar ile genel insanî gelişmeyi destekleyen alanlar arasında denge kurulmas, Yükseköğretimde istihdamın insana yakışır çalışma ilkelerine dayandırılması, (7) Özel yatırım ve kamu-özel ortaklıklarının akademik özgürlüğe olduğu kadar eğitim niteliğine ve hakkaniyete de tehdit oluşturabileceği ve bu nedenle hükümetler tarafından dikkatle düzenlenmesi ve izlenmesi, (8) Eğitim için yeterli finansman kaynaklarının sağlanması ve (10) Eğitimin bir meta değil temel bir insan hakkı olduğu ve herkese açık, eşit ve herkes için erişilebilir olması gerektiğidir yer almaktadır (ILO ve UNESCO, 2018).

Cinsiyet eşitliğini sağlamaya yönelik faaliyetler. UNESCO'nun (2018) Küresel Eğitim İzleme Raporu'nda; cinsiyet eşitliğinin güçlendirilmesinin gerçekleştirilmesinin tüm amaçlar ve hedefler genelinde ilerlemeye önemli bir katkı sağlayacağına, insanlığın yarısı (kadınlar) insan hakları ve fırsatlarından yoksun kalmaya devam ederse küresel gelişimin mümkün olmayacağına, kadınlar ve genç kızların nitelikli eğitime, ekonomik kaynaklara ve siyasî katılımın yanı sıra istihdam, liderlik ve her düzeyde karar alma için erkeklerle eşit fırsatlara sahip olması gerektiğine dikkat çekilmiştir. Bunun yanı sıra, toplumsal cinsiyet eşitliğinin ve kadınların küresel, bölgesel ve ulusal düzeylerde güçlendirilmesi ile ilgili çalışmalar yapan gerekli kurumlara verilen desteğin güçlendirilmesi gerektiğine vurgu yapılmıştır. Yine aynı raporda; dünya bir bütün olarak ele alındığında, yükseköğretim hariç tüm kademelerde cinsiyet eşitliği hedefine ulaşıldığı ancak bu tüm bölgeler, ülke gelir grupları veya tek tek ülkeler için geçerli olmadığ dile getirilmiş olup ülkelerin sadece \%66'sının ilköğretimde, \%45'inin ortaöğretimde ve \%25'inin lise düzeyinde cinsiyet eşitliğine ulaştığının altı çizilmiştir (UNESCO, 2018). UNESCO İstatistik 
Enstitüsü'ne (UNESCO Institute for Statistics [UIS], 2017) göre, 617 milyondan fazla çocuk ve ergenin okuma ve matematikte asgari yeterlilik seviyelerine ulaşamadığı tahmin edilmektedir.

Erken çocukluk eğitimine yönelik faaliyetler. ILO ve UNESCO'nun, erken çocukluk eğitimine (EÇE) yönelik ortak çalışmalar yürüttüğü gözlenmektedir. ILO ve UNESCO'ya (2019b) göre, bu kapsamda 2019 yılında ILO ve UNESCO iş birliğiyle 18 Afrika ülkesinden katılımcıların yanı sıra, aralarında UNICEF ve Dünya Bankası'nun (World Bank) da bulunduğu çeşitli kurum ve kuruluş temsilcilerinin de katılımıla "Nitelikli EÇE ve Eğitimcilerin Profesyonelleşmesi" adlı Afrika Konferansı düzenlenmiştir. Konferans bildirisinde; tüm EÇE öğretmenleri, eğitimcileri ve bakıcıları için hizmet öncesi ve hizmet içi eğitimin kurumsallaşmasının ötesinde, insana yakışır çalışma koşulları ve işlerini etkileyen kararlarda söz hakkı sağlanarak mesleklerinin tanınması ve değerlendirilmesi çağrısında bulunulmuştur. Ayrıca söz konusu bildiride; cinsiyet eşitliğinin EÇE'de tüm yönleriyle desteklenmesi gerektiği üzerinde durulmuş̧tur. Bu nedenle, eğitim emekçileri tarafından kullanılacak eğitim yöntemleri ve içeriğin toplumsal cinsiyet eşitliğini özendiren ve aynı zamanda okul öncesi eğitimden ilkokula geçişi kolaylaştıran müfredatla yönlendirilmesi gerektiği üzerinde durulmuştur. Bunlara ek olarak, engellilik, coğrafi eşitsizlikler, yoksulluk, çatışma ve afetzedelik gibi özel durum ve gereksinimlerin de dikkate alınması gerektiğine dikkat çekilmiştir.

Yine ILO ve UNESCO'ya (2019b) göre, EÇE personeli için insana yakışır işlerin teşvikine ilişkin "2014 ILO Politika Yönergeleri” ve "2019 UNESCO Küresel Profesyonel Öğretim Standartları Çerçevesinin" bu tür konularda rehberlik sağlayabileceği vurgulanmıştır. EÇE personelinin gelişimi, eğitimi, yönetimi ve çalışma koşulları ile ilgili planlama, standart belirleme, uygulama ve izlemenin gerektiği gibi ele alınması ve yeterli düzeyde bütçelendirilmesi için EÇE'nin ulusal veri sistemlerine ve eğitim sektörü planlarına entegrasyonu için bölgesel işbirliği çağrısında bulunulmuştur.

UNICEF ile birlikte yürütülen ortak faaliyetler. ILO ve UNICEF' in (2018) K1z Gücü: Kızlar için Beceriler, Eğitim ve Öğretim (Girl Force: Skills, Education and Training for Girls Now) adlı çalışmasında; az gelişmiş ülkelerde kız çocuklarının eksik becerili (fiziki eşitsizlik) ve aile içerisinde bakıcı rolünde görüldükleri, cinsiyete dayalı beklentiler nedeniyle işgücünün dışında 
bırakıldıkları, savunmasız veya düşük nitelikli istihdama maruz kalma riskiyle karşı karşıya oldukları vurgulanmaktadır. Ayrıca az gelişmiş ülkelerdeki yoksul ailelerinin kız çocuklarının, ilkokul sonrası öğretim düzeyi olan ortaokulları tamamlama düzeyleri erkeklere göre daha düşüktür. ILO ve UNICEF tarafından yapılan son araştırmalar her bölgedeki bazı ülkelerde genç kızların eğitimden işgücüne geçişte karşılaştıkları kalıcı engelleri ortaya çıkarmıştır. Genç kızların ve orta yaş kadınların eğitimdeki kazanımlarına karşın işgücü piyasası sonuçlarındaki cinsiyet eşitsizlikleri devam etmektedir.

ILO'nun Okuldan İşe Geçiş Araştırması'na (School-to-Work Transition Survey, SWTS) göre, genç kadınların işgücü piyasasının dışında olma ve eğitime katılmama olasılı̆̆ 1 genç erkeklere göre üç kat daha fazladır Eğitim ve İstihdamda Yer Almayan Gençler (Not in Education, Employment, or Training, NEET) ${ }^{3}$ verilerine göre, eğitimde ya da istihdamda olmayan genç kadınların oranı \%31 iken genç erkeklerin ise \%16'dır. Bu veriler eğitimde ve istihdam olmayan kadınların oranının erkelerden iki kat daha fazla olduğunu göstermektedir (ILO ve UNICEF, 2018).

Cinsiyet, yaş, eğitim durumu ve göç durumu gibi çeşitli boyutlar NEET olma riskini etkilemektedir. Genç kadınların NEET oranı genç erkeklerden daha fazladır. Ekonomik Kalkınma ve İşbirliği Örgütü (Organisation for Economic Co-operation and Development, OECD) ülkeleri genelinde 18-24 yaş arası kadınların \%15,4'ü NEET iken aynı yaştaki erkekler arasındaki oran \%13,2'dir. Kadınların NEET olasılığı daha yüksek olmasına karşın ne eğitimde ne de istihdam altında olmama nedenleri erkeklerinkiyle aynı değildir. Kadınlar arasında hareketsizliğin ana nedenleri çocuk bakımı sorumlulukları iken erkekler arasında sağlık ve diğer faktörler daha yaygındır. Arjantin, Brezilya, Kolombiya, Kosta Rika, Çekya Cumhuriyeti,

\footnotetext{
${ }^{3}$ NEET; Not in Education, Employment, or Training ya da Not in Employment, Education or Training anlamlarında kullanılır. Türkçe kullanımı; "Eğitimde ve istihdamda yer almayan/bulunmayan/olmayan gençler"dir. 1999 yılında Birleşik Krallık Başbakan Yardımcılığı Sosyal Dışlanma Birimi tarafından hazırlanan "Bridging the Gap" adlı raporda da söz konusu gençlerin "Eğitimde ve istihdamda yer almayan gençler" olarak adlandırılmaları, kavramın iyice yerleşmesini ve politika düzeyinde de kullanılmasını sağlamıştır (Furlong, 2006, s. 556; akt. Yıldız, 2016, s. 21). Kavram, genç işsizliğinden daha geniş bir hedef kitleyi tanımlamakla birlikte daha geniş bir yaş aralığını kapsayacak biçimde günümüzde Avrupa Birliği $(A B)$ ülkeleri tarafından kullanılan önemli bir gösterge haline gelmiştir (Maguire, 2015, s. 122-123; akt. Yıldız, 2016, s. 21).
} 
Meksika ve Türkiye'de, hareketsizlik oranlarındaki cinsiyet farkı 18-24 yaşındakiler arasında en az \%10 fark bulunmaktadır. Meksika ve Türkiye, cinsiyet farkının \%20 olduğu iki OECD ülkesidir (OECD, 2020).

ILO ve UNICEF iş birliğinde yapılan çalışmalara göre, SWTS'nin yapıldığı ülkelerde okula gitmeyen ya da gönderilmeyen kız çocuklarının ekonomik olarak edilgen hale geldiği, gelecekte işgücüne katılmak yerine edilgen olarak kalma eğiliminde olduğu görülmektedir. Eğitim almayan kız çocukları yaş olarak yetişkinliğe doğru ilerledikçe işgücüne katılma olasılığı eğitim almayan erkeklere göre daha düşük oranlarda kalmaktadır. Dolayısıyla yetişkin ve orta yaş kadınların ekonomik hareketsizlik içinde sıkışıp kalmaları daha olasıdır (ILO ve UNICEF, 2018). SWTS'nin yürütüldügü ülkelerde, gerek az gelişmişlik gerekse inançsal tabular ve uygar dünyaya uyum sorunu olması dolayısıyla kız çocuklarının eğitimden uzak bırakılması, akabindeyse doğal olarak işgücü piyasasının dışında kalamaları/bırakılmaları sonucu küçük yaşta evlilik ve annelik olgusuyla da karşıl ve bu da kadınların ileride de işgücüne katılımları üzerinde olumsuz etkiler yaratmaktadır.

Yine SWTS verilerine göre, Bangladeş'te ortaokul çağındaki çocukların neredeyse \%40'ı okula gitmemektedir. Üstelik bunlar, çocuk yaşta evliliklere ve çocuk iş̧̧iliğine karşı savunmasızdırlar. UNICEF tarafından dört yıl önce başlatılan "alternatif öğrenme yolu" programı, okul dışındaki ergenlere beceri eğitimi konusunda yardımcı olmaktadır. Program özellikle kadın katılımcıları önemli ölçüde ve olumlu yönde etkilemiştir. Programın başlangıcından itibaren 14-18 yaşları arasında, yarısından fazlası kız olan, 20.000'den fazla kişi programda eğitim görmüş ve bunların yüzde doksan beşi başarılı bir biçimde iş bulup aylık gelirlerini ortalama altı kat arttırmışlardır (ILO ve UNICEF, 2018).

\section{Tartışma, Sonuç ve Öneriler}

Schiavone'un (2008) belirttiğine göre, ILO yapısında hükümetleri temsil eden 28 kişiden 10'unu sanayileşme bakımından öne çıkan üyeler (şu anda Brezilya, Çin, Fransa, Almanya, Hindistan, İtalya, Japonya, Rusya, Birleşik Krallık ve $A B D)$ tarafından atanmaktadır. Geriye kalan 18 üye ise, yukarıda belirtilen 10 üyenin delegeleri hariç olmak üzere, Konferansa hükümet delegeleri tarafından her üç yılda bir seçilen üyelerden oluşmaktadır. Söz konusu bu durum, sosyal barışı sağlamak gibi temel amaca sahip bir örgütün yapısında 
ve karar mekanizmalarında emperyâl güçlerin baskı rejimi kurmuş olduğunu göstermektedir. Yıldırım (2018), ILO'nun ilk bakışta haddinden fazla demokratik gözüktügünü ancak uygulama aşamasında görünenden farklı olduğunu belirtmektedir. ILO'ya en çok finansal destekte bulunan ülkeler arasında; ABD, Japonya, Almanya, Fransa, İngiltere, İtalya ve Hollanda yer almaktadır. Söz konusu bu durum belirtilen ülkelere diğer ülkelerle karşılaştıııldığında bazı ayrıcalıklar kazandırmaktadır. Bunlardan ilki, bu ülkeler ILO'nun idari yapılanması olan Uluslararası Çalışma Bürosu'nda ödedikleri aidatla orantılı olarak uzman görevlendirme hakkına sahip olmaktadırlar. İkincisi de ILO'daki tüm faaliyetlerin bu ülkelerin dillerinde yürütülmekte olduğudur. Yazar, ILO'nun emperyalist ülkelerin güdümünde ve kontrolünde olduğunu ve bu yapının ancak dünyadaki dengelerin değişmesiyle değişebileceğini ifade etmektedir.

Uluslararası kurum, kuruluş ve örgütlere finansal destekte bulunan ülkeler, bu örgütleri kendi beklenti ve çıarları doğrultusunda yönlendirmektir. Dolayısıyla bu alınan kararlar üzerinde belirleyici olmak ve örgüt kültürünü biçimlendirmek amaciyla bir kapital monarşi oluşturmak istemektedir. Evrensel barış ve ahlâk ilkeleriyle hareket etme amacıyla kurulmuş birçok örgütte bu kapital monarşi ve dünyanın kapital erklerinin yönlendirme izleri görülmektedir. Sevgi (2014) de kapitalist sistem içinde uluslararası örgütlere en fazla finansal kaynak aktaran güçlerin, söz konusu örgütlerin karar alma süreçleri de dâhil olmak üzere birçok faaliyet alanında aktif rol oynama hakkını kendilerinde gördüklerini ifade etmektedir. Bennett ve Oliver, (2015) ABD'nin; ILO'nun üç parçalı olma ilkesinin erozyona uğraması, ILO'nun insan hakları konusuna daha fazla eğilmesi, artan oranda yarg1 sürecini dikkate almaması ve örgütün artan oranda siyasîleşmesi gibi gerekçelerle 1975 yılında önce tehditlerde bulunduktan sonra Kasım 1977'de iki yıldan fazla süre ile ILO üyeliğinden ayrıldığını belirtmektedir. ABD'nin üyelikten ayrılmasıyla birlikte ILO bütçesinin \%25'i karşlanamaz duruma gelmiştir. Örgütün bütçesindeki bu kayıp oranı genel olarak hizmetler ve görevlerde azaltmaya gidilerek karşılanmaya çalışılmıştır.

Sosyal diyalog, başarılı bir eğitim reformu ve eğitim sistemi için birleştirici ve bütünleştirici bir etkiye sahiptir. Eğitim hedeflerinin ve politikalarının kilit noktalarında bu reformu uygulamakta en çok sorumlu olanlar öğretmenler ve öğretmen örgütleridir. Dolayısıyla bu kesimlerin tam katılımı olmadan eğitim sistemlerinden herkes için nitelikli eğitim elde edilmesi beklenemez 
(ILO ve UNESCO, 2003). Sosyal diyalog; eğitim otoriteleri, kamu ve özel sektörde görev yapan öğretmenler ve öğretmen örgütlerinden (Sendikalar, STK'lar) demokratik olarak seçilmiş eğitim emekçisi temsilcileri arasında her türlü bilgi paylaşımı, danışma ve müzakere olarak anlaşılmalıdır. Bu diyalog biçimleri; eğitim hedefleri ve politikaları, mesleğe hazırlık ve öğretmenler için ileri eğitim, öğretmenlerin istihdamı, kariyerleri ve maaşları, haklar ve sorumluluklar ve etkili öğretim ve öğrenim koşulları gibi çeşitli kategorilerde uygulanır. CEART, 2006 raporunda, etkili sosyal diyaloğun belirli temel ilkelere saygı duyulmasına bağlı olduğunu gözlemlemiştir. Diyaloğun temel ön koşulları, demokratik bir kültür, kurallara ve yasalara bağlı ve saygılı ve kurumlar yani bireylerin hem kişisel hem de mesleki temelde günlük yaşamlarını etkileyen konulardaki (müfredat, pedagoji, öğrenci değerlendirmesi vb.) görüşlerini sendikalar veya dernekler aracılı̆̆ıyla bireysel veya toplu olarak ifade etmelerine izin veren mekanizmalardır (ILO ve UNESCO, 2003, 2007). Bir dizi ILO standardı, eğitimde sosyal diyalogla ilgili temeli oluşturan normları sağlamaktadır. En önemli standart, ILO ve UNESCO'nun 1966'da özel ortak konferanslarında oybirliğiyle kabul edilen, Öğretmenlerin Statüsüne İlişkin ILO ve UNESCO Tavsiyesi'dir. Söz konusu bu Tavsiye, hiçbir üye devlet için bağlayıcı değildir. Ancak tarafların çok çeşitli eğitim politikaları konularında eylemlerine rehberlik etmeyi amaçlamaktadır. Tavsiye'nin, üzerinde 50 yıldan fazla bir zaman geçmesine karşın, ilkeleri güncelliğini korumaya devam etmektedir (ILO, 2012).

ILO'nun eğitim emekçilerinin çalışma saatleri, maaşları ve çalışma koşullarına ilişkin tavsiye niteliğindeki kararlar aldığı belirtilmişti. OECD’ye (2020) göre, ilkokul ve ortaokullarda bir öğretmenin sorumlu olduğu ortalama ders yükü saati, ülkeler arasında önemli ölçüde farklılıklar göstermektedir. Ancak öğretmenin yıllık ders yükü saati okul öncesi eğitim düzeyinden ilköğretime, ilköğretim düzeyinden ortaöğretime doğru gittikçe azalma eğilimindedir. Kamu okul öncesi eğitim okullarında zorunlu ders yükü saati OECD ülkeleri ve ekonomileri genelinde yılda ortalama 993 saat olduğu gözlenmektedir. Öğretmenlerin ders yükü saatinin en az olduğu ülke, 519 saatle Meksika iken en fazla olduğu ülke 1755 saat ile Almanya'dır. Bununla birlikte 2000 ve 2019 yılları arasında, OECD ülkelerinde öğretmenlerin ortalama yasal ders yükü saatleri sabit kalmış, ilkokullarda \%2 ve ortaokullarda \%1'den daha az azalmıştır. Ortaokul düzeyindeki okullarda görev yapan öğretmenler çalışma sürelerinin ortalama \%44'ünü öğretim 
faaliyetleri için harcamaktadır. Ancak bu oran Avusturya, İzlanda, Kore, Polonya ve Türkiye'de \%35 veya daha az iken en yüksek orana sahip İskoçya'da (Birleşik Krallık) \%63'e kadar çıkmaktadır. Çalışma süreleri boyunca çoğu ülkedeki öğretmenlerin ders saatleri dışında; planlama/hazırlık, öğrencilerin faaliyetlerini inceleme ve ailelerle iletişim veya iş birliği gibi çeşitli öğretim dışı görevleri de yerine getirmeleri gerekmektedir. OECD ülkeleri ve ekonomilerindeki okul müdürleri, öğretim düzeyine göre yılda ortalama 4345 hafta çalışmaktadırlar. Yıllık yasal çalışma süreleri, okul öncesi düzeyde 1.658 saat, ilkokul düzeyinde 1.630 saat, ortaokul düzeyinde 1.628 saat ve lise düzeyinde ise 1.632 saattir. OECD ülkelerinin yaklaşı üçte ikisinde okul müdürlerinin okulun tatil olduğu günlerde de çalışması gerekmektedir. Avusturya, Fransa, İlanda, Kore, Hollanda, Portekiz, İspanya ve Türkiye'de, ilkokul öğretmenleri, ortaokul öğretmenlerinden en az \%25 daha fazla yıllık öğretim saatine sahiptirler

Ücret/maaş tüm emekçilerin olduğu kadar eğitim emekçilerinin de gelirini ve yaşam düzeyini belirleyen önemli bir ögedir (Bingöl, 1998). OECD’ye (2020) göre, okul öncesi öğretmeni olarak göreve yeni başlayan bir öğretmenin maaşı yıllık 31.996 \$ iken ilkokul öğretmenin 33.914 \$, ortaokul öğretmenin 35.073 \$, lise öğretmeninin ise 36.772 \$'dır. Türkiye'de, ayn düzeylerdeki öğretmenlerin başlangıç maaşları OECD verilerine yıllık toplam 29.407 \$ olarak yansımıştır (bütün düzeylerde aynı başlangıç maaşı). Okul müdürlerinin maaşları ise OECD ülkeleri ve ekonomilerindeki ilk ve ortaöğretimdeki öğretmenlerden ortalama olarak \%53 daha yüksektir. Bu verilerin sağliklı yorumlanabilmesi için sadece standart bir para birimi üzerinden karşılaştırma yapmak yeterli olmamaktadır. Ülkelerin ekonomik gelişmişlikleri, enflasyon göstergeleri, alım güçleri, vergi oranları, söz konusu ülkenin dünya ülkeleri arasındaki gelir grubu türü ve diğer birtakım finansal verilere gereksinim duyulmaktadır. Bütün bunların yanı sıra öğretmenlerin ülkelere göre değişen temel ve zorunlu harcamaları, ek ders saat ücretleri, zorunlu ders saati sayıları da incelenmesi ve yorumlanması gereken diğer değişkenlerdir.

Kamu eğitiminin özelleştirilmesi, dünyanın birçok ülkesinde ekonomik, politik ve kültürel düzlemde genişleyen bir eğilim göstermektedir. Bu durum eğitimin kamusal yönünü özel sektörün lehine olacak biçimde gittikçe belirginsizleştirmektedir (Bernal, 2013). Bunun anlamı, eğitimin her geçen gün biraz daha metalaştırıldığı ve ticarileştirildiğidir. 13. Oturumda da değinildiği 
gibi eğitimin kapital değeri yerine sosyal değerinin galip gelmesi gerekmektedir. Metalaştırılmış eğitimin kurumsal kültürü eğitim emekçilerine çeşitli çalışma güvencesizlikleri şeklinde yansımakta ve yansıtılmaktadır. Bu çalışma güvencesizlikleri özellikle örgütlenme özgürlüğünü tehlikeye atmaktadır. Yine 13. Oturumda dile getirilmiş olan özellikle özel okullardaki sendikasızlaştırma politikaları sonucu eğitim emekçilerini toplu pazarlık ve iş güvencesi başta olmak üzere çeşitli çalışma haklarından yoksun bırakılmaktadır. Locatelli (2019), özel okullarda görev yapan öğretmenlerin genellikle sendikalı olmadığını, bu yüzden de istenildiğinde işten çıkarılabileceğini ve daha düşük ücret aldıkların belirtmektedir. Örneğin Gana'da özel okullardaki öğretmenler aylık 47 \$ maaş alırken, kamu okullarında görev yapan öğretmenlerin maaşı 120-350 \$ arasında değişmektedir. Bangladeş'te kamu okullarında görev yapan öğretmenlerin aylık maaşı 60-140 \$ arasında olduğu görülürken, özel okullarda görev yapan öğretmenlere aylık yaklaşık 20 \$ ödenmektedir (Right to Eduation Prolect [REP], 2014).

CEART'in 13. Oturumunda (2018) vurgulanan bir diğer konu da LGBT öğretmenlerinin maruz kaldığı hak mahrumiyetleri ve diğer sosyal sorunlardır. Bu durum, CEART'ın, dolayısıyla ILO ve UNESCO'nun, cinsel yönelimleri nedeniyle ötekileştirilen öğretmenlerin de her türlü meslek hakkından yararlanması için de çaba ve duyarlılık göstermekte olduğunun bir kanıtı olarak değerlendirilebilir. Özgünlü (2019), aralarında öğretmenlerin de bulunduğu aktif çalışma yaşamında olan LGBT bireyleri üzerinden yürütmüş olduğu çalışmasında, LGBT bireylerinin cinsel yönelimlerinden dolayı işe alma/işten çıkarma gibi yasal ayrımclıkların yanı sıra, küçümseme/hakarete uğrama gibi diğer ayrımcılıklarla karşı karşıya kaldığını ortaya koymaktadır. LGBT bireylerinin çalışma yaşamında karşılaştıkları bu tür ayrımcı davranışlarla başa çıkmada başvurdukları strateji ise genellikle cinsel kimliklerini gizlemektir. Yine 13. Oturumda yerli ve kabile topluluklarından olan belirli öğretmen gruplarının ayrımcılığa maruz kalmalarının dile getirilmiş olması; etnik ve sosyal ötekileştirmenin yanı sıra ayrımcılığa yönelik de CEART'ın duyarlı olduğunu göstermektedir.

Sonuç olarak, düşünsel dayanakları ve ILO'yu oluşturacak koşullar Sanayi Devrimi sonrasında ortaya çıkan işçi sınıfı ve işçi sınıfı sorunlarıdır. Ancak ilerleyen aşamalarda egemen güçler örgütün yönetim yapısında ve karar alma mekanizmasında ağırlıklı olarak yer almıştır. Bu durum gerek örgütün gerekse örgütün yürütmüş olduğu faaliyetlerin finansmanını egemen 
güçlerin hegemonyasına bağımlı hale getirmiştir. Söz konusu bu bağımlılık ilişkisinin kurumsal gelenek haline gelmiş olması, örgütün eğitim hizmet alanına yönelik faaliyetlerine bakış açısını da ortaya koymaktadır. Örgütün eğitim hizmet alanına yönelik geliştirmiş olduğu politikalar, aldığ tavsiye kararları ve çocuk iş̧̧iliğinin önlenmesine dair geliştirdiği bazı düzenlemeler her ne kadar insani bir boyut taşıyor olsa da örgütü ve örgüt yapısını uzun vadede kapitalist liberal ekonominin insana bakış açısıyla uyumlandırmak mümkündür.

ILO ve UNESCO'nun “Öğretmenlerin Statüsüne İlişkin Tavsiyesi (1966)" ve "Yüksek Öğretim Personelinin Statüsüne İlişkin Tavsiye Kararı (1997)" okul öncesinden üniversiteye kadar tüm öğretim düzeylerinde çalışan eğitim emekçilerinin hakları ve sorumluluklarını belirleyen iki uluslararası belgedir. Her iki tavsiye belgesinde kararların kamu kesimini temsil eden hükümetler, özel kesimi temsil eden işverenler ile sendikalarca eğitim ve eğitim emekçileriyle ilgili politikaların belirlenmesinde hangi düzeyde yol gösterici olduğunu ortaya konulmasına yönelik eleştirel çalışmaların yapılması önerilmektedir. 


\title{
EXTENDED ABSTRACT
}

\section{International Labor Organization and Its Education Activities}

\author{
* \\ Hüseyin Yolcu - Engin Alaca \\ Kastamonu University-Anadolu University
}

The ILO was founded on 11th April 1919 and aims to promote opportunities for people around the world to obtain decent work under the conditions of freedom, gender equality, economic security and human dignity. The ILO with tripartite execution mechanism of government, employer, and worker emphasizes social justice and social peace especially in the introduction of the Constitution (ILO, 2020a). In this perspective, it is noteworthy that the description of ILO by Gülmez (2019) as a Social Peace Organization is quite pertinent and appropriate. As Hasgüler and Uludağ (2014) stated, the main objectives of ILO are to promote the establishment of a permanent peace by exerting effort for social justice and contribute to economic and social stability by reorganizing the working conditions with international activities and the quality of life with an innovative approach.

\section{ILO's Education Activities}

ILO has two key institutions for education and training. One of them is the International Institute for Labour Studies which was founded in Geneva in 1961. The Institute holds social and labour policy courses for the governments, industry leaders and researchers. The second one is the International Training Center (ITC), which was founded in Turin, Italy in 1965. The centre's mission is to deliver technical and professional training to the people who were accepted from the developing countries, at a more advanced level than they could get in their countries and also to train teachers.

The ILO considers the persons between the ages of 15 and 24 as young workers and sets the age limit for child labour in 15 years. There have been signs of improvement in child labour problem through including protec- 
tive and developmental legal regulations for child labour in many international texts, such as the European Social Charter (1965), led by ILO and the UN to prevent child abuse and to fight child labour in recent years.

ILO also does researches for education in underdeveloped regions where access to basic human needs is severely limited. The Teachers for International Education Task Force for 2030 or Teacher Task Force 2008, of which ILO is a member, is an exceptional global independent alliance established by the Oslo Declaration that focuses solely on teachers and teacher issues.

The ILO/UNESCO "Recommendation concerning the Status of Teachers (1966)" and "Recommendation concerning the Status of Higher-Education Teaching Personnel (1997)" are two international instruments, which set out principles concerning the rights and responsibilities of teachers, ranging from the pre-school level through university. Both instruments guide governments, employers, teacher unions, and other stakeholders in the crafting of effective teacher policies (ILO and UNESCO, 2019). These recommendations foster personal development and education of teachers and their participation in social and public life for the interests of society. Furthermore, it states that teachers should be free to exercise all civil rights generally enjoyed by citizens (ILO, 2012). Such instruments can be said to be significant in a few aspects. Firstly, these instruments directly address the teachers. Secondly, these instruments, which were prepared by experts from both organizations, guide the education policies of member states. Third, the joint board of the ILO and UNESCO evaluate and report whether these instruments were incorporated by the member states while determining their education policies.

ILO and UNESCO promote qualified teaching principles through the Committee of Experts on the Application of Recommendation Personnel, CEART. The ILO and UNESCO co-founded CEART to promote and monitor the implementation of two international recommendations for teaching staff.

It is observed that ILO and UNESCO are conducting joint studies on early childhood education (ECE). Under this perspective, an African Conference on the "Quality Of Early Childhood Education And The Professionalization Of Educators" was held in collaboration with ILO and 
UNESCO and with the attendance of participants from 18 African countries and representatives of various institutions and organizations, including UNICEF and the World Bank.

The study of ILO and UNICEF named, "Girl Force: Skills, Education and Training for Girls Now (2018)" points out that the girls in underdeveloped countries are under-skilled (physical inequality) and treated as a caregiver in the family, are excluded from the workforce due to gender expectations, are vulnerable or exposed to low-quality employment.

\section{Conclusion}

Consequently, although the ILO is the outcome of a radical intelligence, it has become a predominantly active organization in the governing structure and decision-making mechanism of the sovereign forces. This has made both the organization and the financing activities carried by the organization dependent on the hegemony of sovereign forces. The fact that this dependence relationship has become a corporate tradition also indicates the perspective of the organization's educational activities. Although the policies that are developed by the organization for the education, its recommendations and some regulations to prevent child labour seems to have a human approach, the capitalist liberal economy is quite compatible with the perspective towards the human.

\section{Kaynakça / References}

Ateş, D. (2014). Uluslararası örgütler, devletlerin örgütlenme mantı̆̆ı. Bursa: Dora BasımYayın Dağitım Ltd. Şti.

Bennett, A.L. and Oliver, J. K. (2015). Uluslararası örgütler (N. Uslu, Çev.). Ankara: Bigbang Yayınları.

Bernal, J.L. (2013). Eğitimde kamu hizmetlerinin özelleştirilmesi sonucunda: aile seçimi, sosyal sınıf ve piyasa güçleri (H. Yolcu, Çev.). Eleştirel Pedagoji Dergisi, 5(25), 48-57.

Bingöl, D. (1998). İnsan kaynakları yönetimi (4. bs). İstanbul: Beta Yayınları.

Gürsel, İ. (2016). Çalışan çocuk ve gençlerin korunması. İstanbul Üniversitesi Hukuk Fakültesi Dergisi, 74 (Prof. Dr. Fevzi Şahlanan'na Armağan Sayıs1), 415-464. 
Hasgüler, M. ve Uludağ, M. B. (2014). Devletlerarası ve hükümetler dışı uluslararası örgütler. İstanbul: Alfa Basım Yayım Dağıtım.

Interantional Labor Organization. (2020ö). Issue paper on COVID-19 and fundamental principles and rights at work. 18 Ekim 20120 tarihinde https://www.ilo.org/wcmsp5/groups/public/@ed_norm/@ipec/documents/publication/wcms 757247.pdf adresinden erişildi.

International Labor Organization and United Nations Educational, Scientific and Cultural Organization. (2003). Report, eighth session, joint ILO/UNESCO committee of experts on the application of the recommendations concerning teaching Personnel. Paris: UNESCO.

International Labor Organization and United Nations Educational, Scientific and Cultural Organization. (2007). Report, ninth session, joint ILO/UNESCO committee of experts on the application of the recommendations concerning teaching personnel. Geneva: International Labour Office.

International Labor Organization and United Nations Educational, Scientific and Cultural Organization. (2018). Final report, thirteenth session, joint ILO-UNESCO committee of experts on the application of the recommendations concerning teaching personnel. Geneva: PRODOC.

International Labor Organization and United Nations Educational, Scientific and Cultural Organization. (2019b). Casablanca declaration and call for action, on quality early childhood education and the professionalization of teachers and educators. African Conference on Quality Early Childhood Education (s. 1-4). Casablanca: ILO and UNESCO.

International Labor Organization and United Nations Educational, Scientific and Cultural Organization. (2019a). ILO/ UNESCO recommendation concerning the status of teachers (1966) \& UNESCO recommendation concerning the status of higher-education teaching personnel (1997). Geneva: International Labour Organization and UNESCO.

International Labor Organization and United Nations International Children's Emergency Fund. (2018). Girlforce, skills, education and training for girls now. Geneva: ILO And UNICEF.

International Labor Organization. (2012). Handbook of good human resource practices in the teaching profession. Geneva: International Labour Office.

International Labor Organization. (2016). Rural teachers in Africa: a report for ILO. Geneva: International Labour Office; Centre For International Teacher Education. 
International Labor Organization. (2019). Final report-global dialogue forum on employment terms and conditions in tertiary education. Geneva: International Labour Organization.

International Labor Organization. (2020a). ILO sectoral brief. Geneva: International Labour Office.

International Labor Organization. (2020b). Programme and budget for the biennium 2020-21. Geneva: International Labour Office.

International Labor Organization. (2020c). Spotlight on work statistics; education pays off, but you have to be patient. Geneva: International Labour Office.

International Labour Organization. (2020e). Education sector. 25 Ekim 2020 tarihinde https://www.ilo.org/global/industries-and-sectors/education/lang--en/index.htm adresinden erişildi.

International Labour Organization. (2020f). Report of the thirteenth session of CEART-October 2018. 19 Kasim 2020 tarhinde https://www.ilo.org/sector/activities/sectoral meetings/wcms_671540/lang--en/index.htm adresinden erişildi.

International Labour Organization. (2020g). 13th Session Of The Joint ILOUNESCO Committee of experts on the application of the recommendations concerning teaching personnel (CEART) 18 Ekim 2020 tarihinde https://www.ilo.org/sector/activities/sectoral-meetings/wcms_624033/lang--en/index.htm adresinden erişildi.

International Labour Organization. (2020h). Global dialogue forum on employment terms and conditions in tertiary education. 17 Ekim 2020 tarihinde https://www.ilo.org/wcmsp5/groups/public/---ed_dialogue/---sector/documents/meetingdocument/wcms_644689.pdf adresinden erişildi.

International Labour Organization. (20201). Uluslararası çalı̧̧ma örgütü (ILO) anayasası. 20 Ekim 2020 tarihinde https://www.ilo.org/wcmsp5/groups/public/---europe/---ro-geneva/---ilo-ankara/documents/publication/wcms_412382.pdf adresisinden erişildi.

Kayhan, N. (2012). Çocuk iş̧̧iliği, IPEC deneyimi ışı̆̆ında sanayide çalışan çocukların sorunları. Hukuk ve İktisat Araştırmaları Dergisi, 4(1), 187-200.

Koray, M. (1987). Endüstri ilişkileri. İzmir: Karınca Matbaacılık.

Locatelli, R. (2019). The implications of education privatization. Geneva: PRODOC.

Organisation for Economic Co-operation and Development. (2020). Education at a glance 2020. Paris: OECD Publishing. 
Özgöker, U. (2014). Uluslararası siyasî, askerî ve ekonomik örgütler. İstanbul: Der Yayınları.

Özgünlü, F. (2019). Çalışma yaşamında ayrımcıllk: LGBT'lere yönelik bir araştırma (Yüksek lisans tezi). Beykent Üniversitesi, İstanbul.

Right to Educaton Project. (2014). Privatizations of education. project: action aid international. 22 Kasım 2020 tarihinde https://www.right-to-education.org/resources adresinden erişildi.

Schiavone, G. (2008). International organizations a dictionary and directory. New York: Palgra and Macmillan.

Sengenberger, W. (2014). Uluslararası çalışma örgütü; amaçları, işlevleri ve politik etkileri (O. Tezgel, Çev.). Berlin: Friedrich-Ebert-Stiftung Derneği ve Alman Sendikalar Konfederasyonu.

Sevgi, H. (2014). Uluslararası çalışma örgütü'nün felsefi zemini ve yapısı, örgütün küresel kapitalist sistemdeki pozisyonu ve politikaları (Yüksek lisans tezi). Uludağ Üniversitesi, Bursa.

Türkiye İstatistik Kurumu. (2020). Çocuk işgücü anketi sonuçları, 2019. https://data.tuik.gov.tr/Bulten/Index?p=Child-Labour-Force-Survey2019-33807

Uluslararası Çalışma Örgütü (2020j). 182 No'lu En Kötü Biçimlerdeki Çocuk İşçiliğinin Yasaklanması ve Ortadan Kaldırılmasına İlişkin Acil Eylem Sözleşmesi. 25 Kasım 2020 tarihinde https://www.ilo.org/ankara/conventions-ratified-by-turkey/wcms_377311/lang--tr/index.htm adresinden erişildi.

Uluslararası Çalışma Örgütü (2020m). 138 No'lu Asgari Yaş Sözleşmesi. 25 Kasim 2020 https://www.ilo.org/ankara/conventions-ratified-by-turkey/wcms_377287/lang--tr/index.htm adresinden erişildi.

Uluslararası Çalışma Örgütü (2020n). Uluslararası çalışma enstitüsü. 10 Aralık 2020 http://www.oit.org/ankara/about-us/wcms_372886/lang--tr/index.htm adresinden erişildi.

Uluslararası Çalışma Örgütü. (2014). Uluslararası çalışma örgütü anayasası. Cenevre: ILO.

Uluslararası Çalışma Örgütü. (2020d). ILO'nun tarihçesi. Erişim adresi: 19 Ekim 2020 tarihinde https://www.ilo.org/ankara/aboutus/wcms_372874/lang--tr/index.htm adresinden erişildi.

Uluslararası Çalışma Örgütü. (2020i). Çocuk işçiliği. Erişim adresi: 24 Ekim 2020 tarihinde https://www.ilo.org/ankara/areas-of-work/child-labour/lang--tr/index.htm adresinden erişildi. 
Uluslararası Çalışma Örgütü. (20201). Dünyada 40 milyon kişi modern kölelik koşullarında ve 152 milyon çocuk çalı̧̧ma yaşamında. 20 Ekim 2020 tarihinde https://www.ilo.org/ankara/news/wcms_575650/lang--tr/index.htm adresinden erişildi.

Uluslararası Çalışma Örgütü. (2020o). Uluslararası eğitim merkezi. Erişim adresi: 21 Ekim 2020 tarihinde https://www.ilo.org/ankara/aboutus/wcms_372885/lang--tr/index.htm adresinden erişildi.

United Nations Educational, Scientific and Cultural Organization Institute for Statistics. (2017). More than one-half of children and adolescents are not learning worldwide. Paris: UNESCO.

United Nations Educational, Scientific and Cultural Organization. (2018). Global education monitoring report gender review. Paris: United Nations Educational, Scientific and Cultural Organization.

Vikipedi (2021). Milletler cemiyeti. 05 Mayıs 2021 tarhinde https://tr.wikipedia.org/wiki/milletler_cemiyeti\#: :text=milletler\%20cemiyeti\%20(cemiyet\%2di\%20akvam,sorunlar\%c4\%b1\%20bar\%c4\%b1\%c5\%9f\%c3\%a7\%c4\%b1\%20yollarla\%20\%c3\%a7\%c3\%b6zmek\%20idi adresinden erişildi.

Yıldız, E. (2016). Eğitimde ve istihdamda yer almayan gençler (NEET): Avrupa Birliği gençlik garanti programı ve Türkiye için öneriler (Uzmanlık tezi). Türkiye İş Kurumu, Ankara.

\section{Kaynakça Bilgisi / Citation Information}

Yolcu, H. ve Alaca, E. (2021). Uluslararası çalışma örgütü ve eğitim. OPUS-Uluslararası Toplum Araştırmaları Dergisi, 18(Yönetim ve Organizasyon Özel Sayıs1), 1943-1973. DOI: 10.26466/opus.906780. 